$\xi=-1$

\title{
A Review of Green Supply Chain Management Practices in Asian Countries
}

\author{
Sobia Irum ${ }^{1 *}$, Muhammad Imran Qureshi ${ }^{2}$, Muhammad Ashfaq ${ }^{3}$, Abdul Sami ${ }^{4}$, Mansoor N. Bhatti ${ }^{5}$, Arslan Umar ${ }^{6}$ \\ ${ }^{1}$ Faculty of Management, Universiti Teknologi Malaysia \\ ${ }^{2}$ Malaysian Institute of Industrial Technology, University Kuala Lumpur \\ ${ }^{3}$ Malaysian Institute of Industrial Technology, University Kuala Lumpur \\ ${ }^{4}$ Faculty of Management, Universiti Teknologi Malaysia \\ ${ }^{5}$ Faculty of Management, Universiti Teknologi Malaysia \\ ${ }^{6}$ Faculty of Management, Universiti Teknologi Malaysia \\ *Corresponding Author: Sobiasafdar@Yahoo.Com
}

\begin{abstract}
This paper offers a systematic review of 22 research articles published on the green supply chain management practices in developing Asian countries between 2008 to 2017. With the increasing trend in the depletion of environmental resources, the green supply chain management practices are considered prudent. Their impact on firm's performance has been well established. Review of articles revealed that interest in the topic of green supply chain management practices has grown significantly during the last decade, and will remain a fertile area for academic research in the years to come. Findings revealed that the green supply chain management practices lead to enhanced performance in four areas: economic, environmental, operational, and social.
\end{abstract}

Keywords: Green Supply Chain, Emerging Economies, Sustainability

\section{Introduction}

The fast paced industrialization has led to some adverse environmental impacts like chemical wastes, greenhouse gas emissions and toxic pollutants. In response to this modernization, awareness regarding the environment has also grown. This awareness resulted in green supply chain management. This concept considers sustainability and caring about the management of upstream and downstream supply chain (Walker and Jones, 2012). Most of the manufacturing firms in the developed world have relocated their manufacturing facilities in the developing countries and the reason behind this transfer to Asian countries was the availability of low cost material and cheap labor (Lai et al., 2013). Awareness about the environmental impact of production processes exerted an immense pressure on the Asian countries like China, Malaysia, Indonesia, Taiwan, Thailand and India to bring improvements in their supply chain (Lai and Wong, 2012; Woo et al., 2014). Manufacturing facilities in the Asian countries also realized to reduce the environmental impact of their production. Green supply chain management has attracted the attention of both academia, industry and customers alike (Golicic and Smith, 2013).

This review paper aims to explore the literature on green supply chain management practices and to classify these studies based on development and refinement of green supply chain management practices.

\section{Review-Methodology}

Present study reviewed the literature on green supply chain management practices in databases including: Emerald, Springer, ScienceDirect, Taylor \& Francis, EBSCOhost. The search engines like Google Scholar and Scopus were also used to make sure coverage of publications in other databases. Through systematic literature review, we identified 50 articles published between 2008 to 2017. Search terms were kept broad to avoid limitations. Combination of keywords were used related to the Asian region (China, Malaysia, Taiwan, Thailand and India). For green supply chain management practices, the keywords used were; green purchasing, echo design, supply chain), and for performance outcomes the keywords used were; performance, outcome and benefit. The search resulted in 50 articles published between 2008 and last quarter of 2017. The full text of the articles was studied carefully, and 28 articles were omitted from the review list because their main topic was different from our area of research. Finally, 22 articles were selected for review.

Table 1: List of Reviewed Papers

\begin{tabular}{|l|l|l|l|l|}
\hline $\begin{array}{l}\text { SR } \\
\#\end{array}$ & Article & Region & Methodology & Theory used \\
\hline 1 & $\begin{array}{l}\text { Peng and Lin } \\
(2008)\end{array}$ & Taiwan & Mail Survey & $\begin{array}{l}\text { Institutional } \\
\text { theory }\end{array}$ \\
\hline 2 & $\begin{array}{l}\text { Yang et al } \\
(2010)\end{array}$ & $\begin{array}{l}\text { China \& } \\
\text { Taiwan }\end{array}$ & Mail Survey & NS \\
\hline 3 & $\begin{array}{l}\text { Wong et al } \\
(2011)\end{array}$ Thailand & Mail Survey & $\begin{array}{l}\text { Contingency } \\
\text { Theory }\end{array}$ \\
\hline 4 & $\begin{array}{l}\text { Chan et al } \\
(2012)\end{array}$ & Taiwan & Mail Survey & $\begin{array}{l}\text { Resource based } \\
\text { view }\end{array}$ \\
\hline 5 & $\begin{array}{l}\text { Zailani et al } \\
(2012)\end{array}$ & Malaysia & E-mail Survey & $\begin{array}{l}\text { Institutional } \\
\text { Theory }\end{array}$ \\
\hline 6 & $\begin{array}{l}\text { Lai et al } \\
(2013)\end{array}$ & China & Mail Survey & $\begin{array}{l}\text { Production } \\
\text { frontier Theory }\end{array}$ \\
\hline 7 & $\begin{array}{l}\text { Nagarajan et } \\
\text { al (2013) }\end{array}$ & India & Survey & $\begin{array}{l}\text { Resource } \\
\text { Based View }\end{array}$ \\
\hline 8 & $\begin{array}{l}\text { Ye et al } \\
(2013)\end{array}$ & China & Mail Survey & $\begin{array}{l}\text { Institutional } \\
\text { Theory }\end{array}$ \\
\hline
\end{tabular}




\begin{tabular}{|c|c|c|c|c|}
\hline 9 & $\begin{array}{l}\text { Lee et al } \\
(2013)\end{array}$ & Malaysia & Mail Survey & NS \\
\hline 10 & $\begin{array}{l}\text { Abdullah and } \\
\text { Yakub (2014) }\end{array}$ & Malaysia & E mail Survey & NS \\
\hline 11 & $\begin{array}{ll}\text { Cheng, } & \text { Yang } \\
\text { and } & \text { Sheu } \\
(2014) & \\
\end{array}$ & Taiwan & Mail Survey & $\begin{array}{l}\text { Resource based } \\
\text { view }\end{array}$ \\
\hline 12 & $\begin{array}{l}\text { Hung Chen } \\
\text { and Chung } \\
(2014)\end{array}$ & Taiwan & Mail Survey & $\begin{array}{l}\text { Social Capital } \\
\text { Theory }\end{array}$ \\
\hline 13 & $\begin{array}{lll}\text { Chan et } \\
(2015)\end{array}$ & China & Survey & $\begin{array}{l}\text { Contingency } \\
\text { Theory }\end{array}$ \\
\hline 14 & $\begin{array}{l}\text { Dubey et al } \\
(2015)\end{array}$ & India & $\begin{array}{l}\text { Electronic Sur- } \\
\text { vey }\end{array}$ & $\begin{array}{l}\text { Institutional } \\
\text { Theory }\end{array}$ \\
\hline 15 & $\begin{array}{l}\text { Lee et al } \\
(2015)\end{array}$ & Malaysia & Mail Survey & $\mathrm{NS}$ \\
\hline 16 & $\begin{array}{l}\text { Zailani et al } \\
\text { (2015) }\end{array}$ & Malaysia & Survey & $\begin{array}{l}\text { Institutional } \\
\text { Theory }\end{array}$ \\
\hline 17 & $\begin{array}{l}\begin{array}{l}\text { Aziz et al } \\
(2016)\end{array} \\
\end{array}$ & Malaysia & $\begin{array}{l}\text { Email survey and } \\
\text { Interview }\end{array}$ & NS \\
\hline 18 & $\begin{array}{l}\text { Lo and Shiah } \\
\text { (2016) }\end{array}$ & Taiwan & $\begin{array}{l}\text { Questionnaire } \\
\text { Survey }\end{array}$ & $\begin{array}{l}\text { Contingency } \\
\text { Theory }\end{array}$ \\
\hline 19 & $\begin{array}{l}\text { Khor et al } \\
(2016)\end{array}$ & Malaysia & Survey & $\begin{array}{l}\text { Institutional } \\
\text { Theory }\end{array}$ \\
\hline 20 & $\begin{array}{l}\text { Gopal and } \\
\text { Thakkar } \\
(2016)\end{array}$ & India & Survey & NS \\
\hline 21 & $\begin{array}{l}\text { Zhao et al } \\
\text { (2017) }\end{array}$ & China & $\begin{array}{l}\text { Optimization } \\
\text { Model }\end{array}$ & NS \\
\hline 22 & $\begin{array}{l}\text { Zhu et al } \\
\text { (2017) }\end{array}$ & China & $\begin{array}{l}\text { Questionnaire } \\
\text { survey }\end{array}$ & NS \\
\hline
\end{tabular}

After the review of 22 research articles about green supply chain management practices following journals were identified in which the largest share of articles were published from 2008 till 2017. Table 2 depicts the information about the distribution of articles on the basis of journal.

Table 2: Number of Papers by Journal

\begin{tabular}{|l|l|l|}
\hline $\mathbf{S r} \#$ & Name of Journal & Number of Articles \\
\hline 1 & $\begin{array}{l}\text { International Journal of Production Eco- } \\
\text { nomics }\end{array}$ & 8 \\
\hline 2 & Journal of Cleaner Production & 3 \\
\hline 3 & Production Planning and control & 2 \\
\hline 4 & Journal of operations Management & 1 \\
\hline 5 & Journal of Business Ethics & 1 \\
\hline 6 & Industrial Marketing Management & 1 \\
\hline 7 & $\begin{array}{l}\text { Asia Pacific Journal of Marketing and } \\
\text { Logistics }\end{array}$ & 1 \\
\hline 8 & Management Decision & 1 \\
\hline 9 & International Journal of Business & 1 \\
\hline 10 & $\begin{array}{l}\text { Technology Analysis and Strategic Man- } \\
\text { agement }\end{array}$ & 1 \\
\hline 11 & Procedia Social and Behavioral Sciences & 1 \\
\hline 12 & $\begin{array}{l}\text { Supply chain Management an Interna- } \\
\text { tional Journal }\end{array}$ & 1 \\
\hline
\end{tabular}

Table 2 provides list of papers published in the top tier journals, most of the reviewed papers were published in high-ranked journals which emphasize the quality of this systematic review. The leading journal here is the, International Journal of Production Economics having eight published articles followed by Journal of Cleaner production with three articles and Production Planning and Control with two articles. The remaining articles were published in other journals as depicted in table 2 .

\section{Results}

Table 3: List of Theories used

\begin{tabular}{|l|l|l|}
\hline \multicolumn{3}{|c|}{ Table 3: List of Theories used } \\
\hline Sr \# & Theory & No of Articles \\
\hline 1 & Institutional Theory & 6 \\
\hline 3 & Contingency Theory & 3 \\
\hline 4 & Resource Based View & 3 \\
\hline 5 & Social Capital Theory & 1 \\
\hline
\end{tabular}

Table 3 depicts the theoretical perspective on which the research articles were based. Institutional theory was the most widely used theory in the articles regarding green supply chain management practices. Followed by contingency theory used in three articles and the other important theory turned out to be resource based view, which is also used in three articles. Social Capital theory and Production frontier theory had been used in one article each. Some of the articles included in the review have not adopted any specific theory. Institutional theory was used to identify the external drivers including competitors, customers, suppliers etc. on the other hand Contingency theory had been used for explaining the relationship between green supply chain management practices and performance. While the usage of contingency theory explained that the organizations are open system and the environment effects their performance.

Table 4: Number of papers by Methodology

\begin{tabular}{|l|l|l|}
\hline $\mathrm{Sr} \#$ & Methodology used & Number of papers \\
\hline 1 & CB-SEM & 8 \\
\hline 2 & Multivariate Linear Regression & 4 \\
\hline 3 & Path Analysis & 2 \\
\hline 4 & PLS-SEM & 5 \\
\hline 5 & Hierarchal Regression & 1 \\
\hline 6 & Factor Analysis & 2 \\
\hline
\end{tabular}

Moreover, it was found from the literature that majority of the papers included in the review applied CB-SEM data analysis method to find the relationship among the variables. Table 5 shows that eight articles out of 22 have used CB-SEM. The other most widely used methodology was PLS-SEM, which was used in five articles. Multivariate linear regression was also found to be the next most used methodology in the articles reviewed. From this review it can be concluded that the structural equation modelling has becoming a famous methodological tool for researches in the field of green supply chain management.

Review of literature revealed that, most research articles have drawn the samples from different companies and industries. Many of the researchers have collected data from multiple sectors, for example (Nagarajan et al 2013). While, some researchers taken their sample from only one industry like automotive, for example (Zailani, 2015). An interesting finding on the basis of literature review was that some articles highlighted the strong relationship between firm performance and green supply chain management practices for ISO 14001 certified companies (Zailani et al, 2015), while in case of Malaysia Lee et al (2013) has found an insignificant relationship between green supplier and environmental performance among ISO 14001 certified firms. As the cost of obtaining ISO certification is high that might result in utilizing the firm resources away from investing in these processes (Ann et al , 2006).

Review of the articles revealed that the green supply chain management practices and firm performance relationship has been narrated in four dimensions: Social, Economic, operational and environmental. While the main goal of these developing Asian countries is still the economic development, but since the global focus is on environmental issues, this compelled them to improve their environmental performance as well (Lee et a., 2013). Social issues like labor conditions and product safety has recently attracted the attention of researchers in developing Asian countries. On the front of social performance, Zailani et al. (2012) investigated data from manufacturing firms in Malaysia and concluded that green purchasing and green packaging adoption by the firms resulted in a positive effect on social performance. An important aspect of social issue is the labor conditions in the developing Asian countries. Literature review revealed that labor conditions are playing more significant role in manufacturing supply chains. It has become an important area of concern for the firms to improve their labor conditions so as to conform to the green supply chain management practicing.

On the side of economic performance, it was found that there is a positive relationship between green supply chain management practices and firm's economic performance, initially it requires huge investment but that pays in the long run. Review of the prior 
research also identified positive relationship between green supply chain management practices and firm's environmental performance. Zhu et al. (2013) advocated that elimination of waste results in substantial improvements in environmental performance. Similarly, product and process innovation can lead to higher environmental performance.

Our review also found a positive association between the green supply chain management practices and operational performance of a firm. By recycling of the waste, decreasing the scrap rate and delivery time can considerably add to the firm's operational performance (Dou et al., 2013; Lee et al., 2013). The positive relationship between green supply chain management practices and social performance was also endorsed by the review of literature. In case of Malaysia it was found that green purchasing and green packaging positively affected the firm's social performance (Zailini et al. 2012). Social performance is a vital factor in sustainable supply chain.

\section{Conclusion}

This review of literature on green supply chain management practices in the developing asian countries revealed that the relationship between firm performance and green supply chain management practices is very strong. The firm performance in this study is taken as the summation of social, economic, environmental and operational performance. Review of literature also confirmed that the green supply chain management practices and performance relationship is strongest in case of economic performance as compared to operational performance and environmental performance, while green supply chain management practices have been found to have no significant effect on social performance. However, the initial costs of adopting the green supply chain management practices is high but the benefits in the long run like; energy saving, waste reduction, operational efficiency, employee satisfaction and customer image can outweigh the costs.

\section{References}

[1] Abdullah, N.A.H.N., Yaakub, S., 2014, Reverse logistics: pressure for adoption and the impact on firm's performance. Int. J. Bus. Soc. 15 (1), 151.

[2] Ann, G.E., Zailani, S., Wahid, N.A., 2006. A study on the impact of environmental management system (EMS) certification towards firms' performance in Malaysia. Manag. Environ. Qual.: Int. J. 17 (1), 73-93

[3] Aziz, T. N. A. T., Jaafar, H. S., Tajuddin, R. M., 2016, Green supply chain: Awareness of logistics industry in Malaysia. ProcediaSocial and Behavioral Sciences, 219, 121-125.

[4] Chan, R.Y.K., He, H., Chan, H.K., Wang, W.Y.C., 2012. Environmental orientation and corporate performance: the mediation mechanism of green supply chain management and moderating effect of competitive intensity. Ind. Mark. Manag. 41 (4), 621-630.

[5] Chan, H.K., Yee, R.W., Dai, J., Lim, M.K., 2015, The moderating effect of environmental dynamism on green product innovation and $\begin{array}{llll}\text { performance. Int. J. Prod. } & \text { Econ.http:// }\end{array}$ dx.doi.org/10.1016/j.ijpe.2015.12.006.

[6] Cheng, C.C., Yang, C., Sheu, C., 2014, The link between ecoinnovation and business performance: a taiwanese industry context. J. Clean. Prod. 64, 81-90. http:// dx.doi.org/10.1016/j.jclepro.2013.09.050

[7] Dubey, R., Gunasekaran, A., Ali, S.S., 2015, Exploring the relationship between leadership, operational practices, institutional pressures and environmental performance: a framework for green supply chain. Int. J. Prod. Econ. 160, 120-132.

[8] Golicic, S.L., Smith, C.D., 2013, A meta-analysis of environmentally sustainable supply chain management practices and firm performance. J. Supply Chain Manag. 49 (2), 78-95.

[9] Gopal, P., Thakkar, J., 2015, Sustainable supply chain practices: an empirical investigation on Indian automobile industry. Prod. Plan. Control 27 (1), 49-64.

[10] Hung, S.-W., Chen, P.-C., Chung, C.-F., 2014, Gaining or losing? The social capital perspective on supply chain members' knowledge sharing of green practices. Technol. Anal. Strateg. Manag. 26 (2), 189-206.
[11] Khor, K. S., Udin, Z. M., Ramayah, T., Hazen, B. T. 2016, Reverse logistics in Malaysia: The contingent role of institutional pressure. International Journal of Production Economics, 175, 96-108.

[12] Lai, K., Wu, S.J., Wong, C.W.Y., 2013, Did reverse logistics practices hit the triple bottom line of Chinese manufacturers? Int. J. Prod. Econ. 146 (1), 106-117.

[13] Lai, K., Wong, C.W.Y., 2012, Green logistics management and performance: some empirical evidence from Chinese manufacturing exporters. Omega 40 (3), 267-282.

[14] Lee, S.M., Rha, J.S., Choi, D., Noh, Y., 2013, Pressures affecting green supply chain performance. Manag. Decis. 51 (8), 14.

[15] Lee, S., 2015, The effects of green supply chain management on the supplier's performance through social capital accumulation. Supply Chain Manag.: Int. J. 20 (1), 42-55.

[16] Lo, S. M., Shiah, Y. A. 2016, Associating the motivation with the practices of firms going green: the moderator role of environmental uncertainty. Supply Chain Management: An International Journal, 21(4), 485-498.

[17] Nagarajan, V., Savitskie, K., Ranganathan, S., Sen, S., Alexandrov, A., 2013. The effect of environmental uncertainty, information quality, and collaborative logistics on supply chain flexibility of small manufacturing firms in India. Asia Pac. J. Mark. Logist. 25 (5), 784-802

[18] Peng, Y.-S., Lin, S.-S., 2008, Local responsiveness pressure, subsidiary resources, green management adoption and subsidiary's performance: evidence from Taiwanese manufactures. J. Bus Ethics 79 (1-2), 199-212.

[19] Qureshi, M.I., Rasli, A.M. Zaman, K., 2016, Energy crisis, greenhouse gas emissions and sectoral growth reforms: Repairing the fabricated mosaic, Journal of Cleaner Production, 112, 3657-3666.

[20] Rasli, A.M., Qureshi, M.I., Isah-Chikaji, A., Zaman, K. Ahmad, M., 2017, New toxics, race to the bottom and revised environmental Kuznets curve: The case of local and global pollutants, Renewable and Sustainable Energy Reviews, 81, 3120-3130. 